Govedar, Z., Kanjevac, B., Velkovski, N. (2021): Diameter structure stand and time of passage trees: An analysis in primeval forests Janj and Lom in Republic of Srpska (Bosnia and Herzegovina). Agriculture and Forestry, 67 (4): 89-102. doi:10.17707/AgricultForest.67.4.09

DOI: 10.17707/AgricultForest.67.4.09

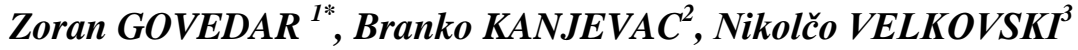

\section{DIAMETER STRUCTURE OF THE STAND AND TIME OF PASSAGE: AN ANALYSIS IN PRIMEVAL FORESTS JANJ AND LOM IN REPUBLIC OF SRPSKA (BOSNIA AND HERZEGOVINA)}

\section{SUMMARY}

The research was carried out in primeval forest stands of beech, fir and spruce (Piceo-Abieti-Fagetum illyricum) on brown dolomite soils (Janj) and dominantly shallow limestone soils (Lom). The diameter structure is typical for primeval forests with the participation of large trees in which physiological weakening is visible, especially in the Lom primeval forest. At the same time, the stands are characterized by the specifics of the transition from the terminal to the initial development phase, with a very pronounced lower floor of the stands where beech and fir dominate. Significant differences in the size of the diameter increment are characteristics for fir, which in the Lom primeval forest has a significantly higher diameter increment at the same diameters than in Janj. The current diameter increment of fir in Janj is $2.3 \mathrm{~mm} /$ year and in Lom $4.5 \mathrm{~mm} /$ year. The average current thickness growth of spruce in Janj is $0.2 \mathrm{~mm}$ higher on average than in Lom and amounts to $2.9 \mathrm{~mm} /$ year. The current thickness growth of beech in Lom is significantly higher $(4.9 \mathrm{~mm} /$ year) than in Janj $(2.3 \mathrm{~mm} /$ year $)$. The average time of passage is the highest for fir in the Janj primeval forest and for the whole stand is 45 years, and the lowest for spruce in the Lom primeval forest 22 years. Beech trees in the lowest diameter classes have a significantly shorter time of passage than fir and spruce. Fir in the Janj forest has an average relative age of 85 years higher than in Lom. Spruce shows the largest difference in relative age between primeval forests in thinner diameter classes, and unlike fir, the difference in age decreases with increasing diameter.

Keywords: stand structure, time of passage, diameter increment, primeval forests

\footnotetext{
${ }^{1}$ Zoran Govedar (Corresponding author: zoran.govedar@sf.unibl.org), University of Banja Luka Faculty of Forestry, Banja Luka, Republic of Srpska, BOSNIA AND HERZEGOVINA

${ }^{2}$ Branko Kanjevac, Violeta Babic, University of Belgrade - Faculty of Forestry, Belgrade, SERBIA

${ }^{3}$ Nikolco Velkovski, s. Cyril and Methodius University in Skopje, Hans Em Faculty of Forest Sciences, Landscape Architecture and Environmental Engineering, NORTH MACEDONIA Notes: The author declares that he has no conflicts of interest. Authorship Form signed online. 


\section{INTRODUCTION}

Old growth forests cover is only around 3\% of EU forested land and being of paramount importance (Barredo et al., 2021). Old-growth stands have developed for a long period of time without relevant human impact. Structural characteristics of old-growth forests represent a worthy model for management and structuring of managed forests (Motta et al., 2015; Vasic et al., 2018; Chivulescu et al., 2019; Curovic et al., 2020). Mixed coniferous and deciduous forests in the area of beech, fir and spruce forests in Bosnia and Herzegovina occupy 716.200 ha. In these forests of production character, the average volume is $309.95 \mathrm{~m} 3 / \mathrm{ha}$. The average current volume increment is $7.91 \mathrm{~m} 3 / \mathrm{ha}$. Management is often based on a selection-tree system, and the obsolescence of the offspring, the reduction of the canopy, and the lack of care measures are the basic problems in management. Former notions of natural harmony contained in the permanent selective structure of primeval forests and the pursuit of a similar situation in commercial forests have become a dangerous unnatural creation without the ability to self-sustain.

Due to different intensities of felling and creation of different conditions for tree canopy development in commercial forests, diameter increase is very variable, and in primeval forests the transition of trees from lower to higher diameter classes mainly depends on spontaneous natural processes of different development phases, habitat conditions and tree species. The time of passage means the average number of years required for all trees of a diameter class to grow the entire width of the same and move to a higher diameter class (Miletić, 1950). Knowing the time of passage is of special importance for forest management because its knowledge determines the average time dynamics of tree diameter changes, which is reflected in the horizontal structure of stands. In addition, the time of passage is important for the proper selection and care of the crop trees. By removing diseased and trees of poor phenotype, we reduce the time of passage (Govedar, 2005). The average time of passage of individual diameter classes is almost equal at higher tree thicknesses.

In the selective forest, the width of the rings usually increases with the age of the trees, and from a certain diameter it is maintained at the same amount. In this phenomenon of permanent maintenance of rings at the same width, and therefore of equal diameter increment, certain legality can be seen, confirmed for both fir and spruce, the types of trees most suitable for selective management (Hufnagl, 1939). However, deviations from this regularity may occur because in stronger diameter classes there may be a re-increase in the time of passage in fir and spruce in better habitat conditions, which is caused by the presence of usually obsolete trees of poorer vitality (Flury, 1932). If the sum of the time of passage (relative age) is shorter, it indicates more favorable habitat conditions, so this parameter may additionally affect the productivity assessment. This paper aims to determine the average time of passage of trees from lower to higher diameter classes as well as their relative age. 


\section{MATERIAL AND METHODS}

The research was carried out in the Janj and Lom primeval forests in mixed stands of fir, spruce and beech, which phytocoenologically belong to the PiceoAbieti-Fagetum illyricum community. The Janj primeval forest reserve was set aside in 1954 as a facility for scientific research, with a total area of 295 ha. In September 2021, it was declared as a natural world heritage site by UNESCO. This natural asset on the territory of the municipality of Šipovo is protected by the highest category Ia, according to the classification of the International Union for Conservation of Nature (IUCN). The Janj old-growth forest reserve is located on the Stolovaš mountain, between $44^{\circ} 07^{\prime}$ and $44^{\circ} 10^{\prime}$ north latitude and between $17^{\circ} 15^{\prime}$ and $17^{\circ} 17^{\prime}$ east longitude. The primeval forest is located between 1.180 and 1.510 meters above sea level (Fig. 1). The Lom old-growth forest reserve was protected in 1956 as a strict nature reserve in which economic activity was prohibited. It is located between $44^{\circ} 27^{\prime}$ and $44^{\circ} 28^{\prime}$ north latitude and between $16^{\circ} 27^{\prime}$ and $16^{\circ} 30^{\prime}$ east longitude. The reserve belongs to the massif of the mountain Klekovača, on the Lom mountain. The altitude amplitude is from 1.250 to 1.522 meters above sea level.

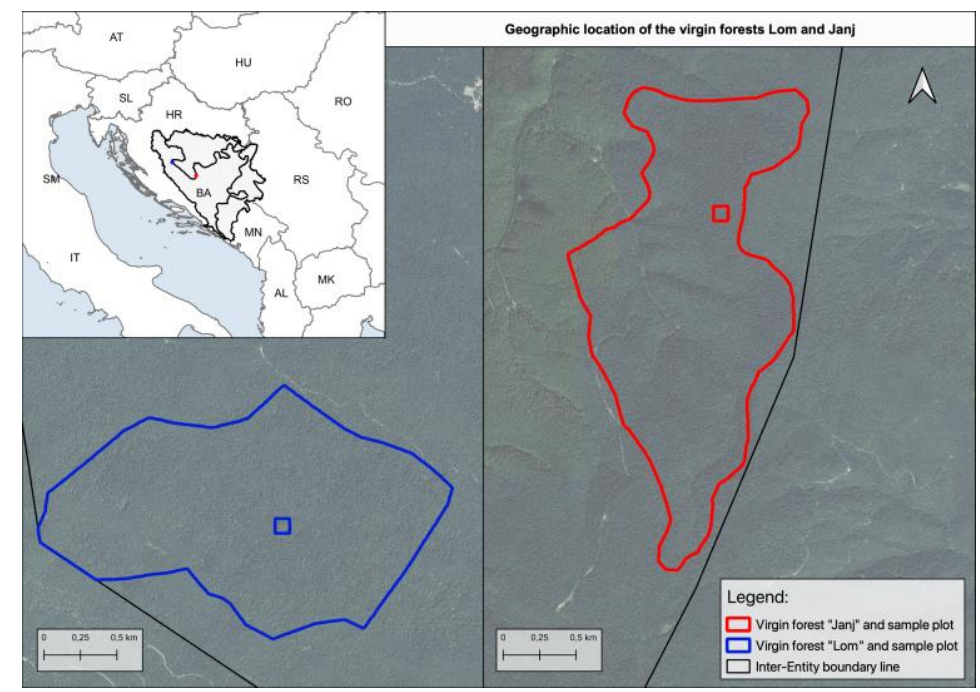

Figure 1. The geographic location of the sample plots

According to the ecological-vegetative regionalization of $\mathrm{BiH}$ (Stefanovic et al. 1983), the stands belong to the area of the inner Dinarides, the western Bosnian, limestone-dolomite area. The Janj primeval forest is dominated by dolomite, and the Lom primeval forest by a limestone geological base and typical soils of calcomelanosol, calcocambisol and luvisol have developed on them. The research area is dominated by the mountain perhumid climate which is characteristic of the inner Dinarides. According to the classification system, the stands are different concerning the degree of stoniness, which is much more pronounced in the Lom primeval forest and can mainly be classified into two 
types of forests (Ćirić et al., 1971): mixed beech, fir and spruce forests on brown dolomite soils (Janj ) and forests on dominantly shallow limestone soils (Lom).

In each stand, there is one experimental area of $100 \times 100 \mathrm{~m}$. All diameters and heights of all trees with diameters larger than $5.0 \mathrm{~cm}$ were measured. To determine the dependence of tree heights (h) on their diameters (d), the Prodan function was used:

$$
\mathrm{h}=\mathrm{d}^{2} /\left(\mathrm{a}+\mathrm{ad}+\mathrm{ad}^{2}\right)+1.30
$$

Determination of site class by tree species was performed using site classes dispositions for fir, spruce and beech that are valid in BiH (Drinić et al. 1980). To determine the site class, the assumption was used that only tree heights thicker than $50 \mathrm{~cm}$ are favorable for it. In each diameter class, wood samples were taken from 5 fir, spruce and beech trees using a Pressler drill. The dependence of the current diameter increment of fir and spruce on the diameter was determined by applying a second-order parabola. The average times of passage were determined by diameter classes and tree species by the direct method based on the taken samples. The average time of passage of the entire stand is determined by the formula:

$$
T_{\text {sast. }}=\frac{\sum n_{i} t_{i}}{\sum n_{i}} ;
$$

$\mathrm{T}_{\text {sast. }}$ - the average time of passage of the entire stand,

$\mathrm{n}_{\mathrm{i}}$ - number of trees in the $\mathrm{i}$ - th diameter class,

$t_{i}$ - the average time of passage of trees of the , i“ diameter class.

\section{Diameter structure}

\section{RESULTS AND DISCUSSION}

The main feature of the diameter structure of trees in primeval forests is the presence of very thick ancient trees of a specific phenotype (Govedar et al. 2018). The total number of trees in Janj is 588 per ha, and in the Lom 548 per ha. The ratio of mixture to the number of trees in the Janj stand was fir (41.4\%), beech $(35.6 \%)$, spruce $(23.0 \%)$, and in Lom beech $(47.6 \%)$, fir $(35.4 \%)$ and spruce $(17.0 \%)$. The analysis of the diameter structure shows several generations of trees in both primeval forests (Fig. 2). Beech dominates in the lower diameter classes, and the low presence of spruce is caused by insufficient ingrowth, so the spruce failed to develop into the category of trees above the taxation limit. Intensive natural regeneration of beech and dominance in thinner diameter classes in primeval forests usually occurs after fires and destruction by winds (Tregubov, 1941; Šafar, 1955), which causes the appearance of structural forms that are characteristic of stands with fast and short regeneration (Klepac, 1963). Such structural forms characterize primeval forests that are in the initial phase of development where the natural competitive power of beech dominates. Abundant 
regeneration of beech in places of the broken canopy and at the same time its predominance in thinner diameter classes is a natural phenomenon that accompanies the development of primeval forests in the Dinarides, so it is "a hasty conclusion about the change of species" (Fukarek, 1965). The oldest generation of trees consists mainly of ancient very developed and tall fir and spruce trees of a specific phenotype. In these trees, there is a visible physiological weakening (especially in the Lom primeval forest) and signs of disease from various species of rot Armillaria mellea, Fomes annosus and others.
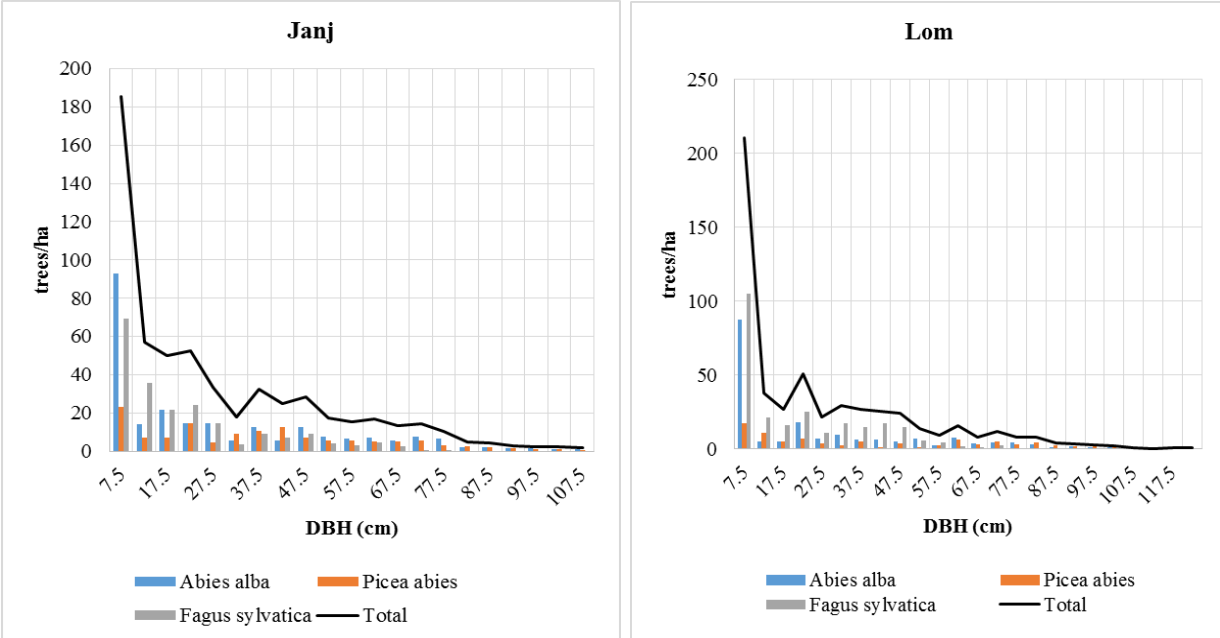

Figure 2. Diameter distribution of trees in primeval forests Janj and Lom

In the category of the largest trees in both primeval forests, the representation of fir and spruce is approximately equal, and beech trees are not represented in the category of the thickest trees in stands. According to the classification of Korpel (1995), stands still have more characteristics of the ingrown stage and a more pronounced initial phase of development within this stage. The basic characteristics of developmental phases (duration, structure, spatial distribution, etc.) depend, among other things, on the length of life of tree species that build a primeval forest, which is why it is necessary to know the times of passage and relative age of trees. Analyzing the diameter structure of stands in Janj and Lom primeval forests, it can be concluded that the stands are characterized by the specifics of the terminal and initial phase, with a pronounced lower floor of the stand where beech and fir trees dominate and the upper floor where dominate ancient fir and spruce trees.

\section{Height curves and stand site class}

The height curves in primeval forests do not have a typical esoid shape, and the point of inflection in all curves is located to the right of the $\mathrm{Y}$-axis near the coordinate origin. In the primeval forests, graphically expressed functional dependence of height on diameter represents the height curve of development, 
because it is subject to changes in a longer period (Milin, 1965; Stamenković, 1974). It was determined that the main tree species belong mainly to the second site class (Tab. 1). A slower flow of curves occurs when the tree comes to higher light and then the tree yields in height, and intensifies the diameter increment (Rozenbergar et al. 2007), and this is characteristic of one-season stands of low growth (Drinić, 1956). The investigated stands are of normal and very good overgrowth, so their height growth is still intense, especially in spruce trees. Fir in Lom reaches higher heights at the same diameters, so it belongs to a better quality (Fig. 3). Medium-thick and thick trees are on average about $3.0 \mathrm{~m}$ higher in height in Janj than in Lom. These differences in heights did not cause differences in site class, so spruce in both primeval forests belongs to the II site class. Earlier research related to the Klekovača primeval forest indicates that up to a diameter of $30 \mathrm{~cm}$ there are no significant differences in the heights of beech, fir and spruce, and in the primeval forest on Grmeč these differences are not observed up to $20 \mathrm{~cm}$ in diameter (Tregubov, 1941; Miletić, 1950). However, our research indicates that there are significant differences in the heights of these tree species in thinner trees and that fir and spruce trees belong mainly to site class II, which was found in previous research in the same primeval forests (Drinić, 1956; Keren, 2015). Statistical indicators show a relatively strong dependence of tree heights on their diameters with high coefficients of determination (Table 1).

Table 1. Basic statistical indicators of height curves for stands Janj and Lom

\begin{tabular}{cccccccc}
\hline $\begin{array}{c}\text { Primeval } \\
\text { forest }\end{array}$ & \multirow{2}{*}{ Tree species } & \multicolumn{2}{c}{$\mathrm{h}=\mathrm{d}^{2} /\left(\mathrm{a}+\mathrm{ad}+\mathrm{ad}^{2}\right)+1,30$} & & & \\
\cline { 3 - 8 } Janj & Abies alba & 5.5046 & 0.6630 & 0.0202 & 98.5 & 1.14 & II \\
& Picea abies & 9.5387 & 0.2340 & 0.0228 & 89.6 & 2.86 & II \\
& Fagus sylvatica & -0.9180 & 0.7823 & 0.0220 & 75.6 & 3.01 & III \\
\hline \multirow{2}{*}{ Lom } & Abies alba & 6.8039 & 0.4840 & 0.0197 & 71.4 & 4.37 & I \\
& Picea abies & 4.5473 & 0.6313 & 0.0200 & 83.7 & 3.88 & II \\
& Fagus sylvatica & -1.2380 & 1.0639 & 0.0158 & 79.0 & 4.07 & II \\
\hline
\end{tabular}

$\mathrm{a}, \mathrm{b}, \mathrm{c}$ - parameters of function; $\mathrm{R}^{2}$ - coefficient determination; $\mathrm{Se}$ - statistical error

In the Janj primeval forest, the height growth of fir is smaller than the height growth of spruce up to $37.5 \mathrm{~cm}$, after which it is larger and the difference is approximately constant and averages about $0.2 \mathrm{~m}$. In the Lom primeval forest, the height growth of fir trees is higher than spruce trees, but with increasing diameter, this difference decreases, so that with a diameter of about $67.5 \mathrm{~cm}$, it is insignificant and the growths are almost equal. Fir in Lom reaches higher heights than spruce. With thinner diameter classes, no significant difference in heights is observed. 

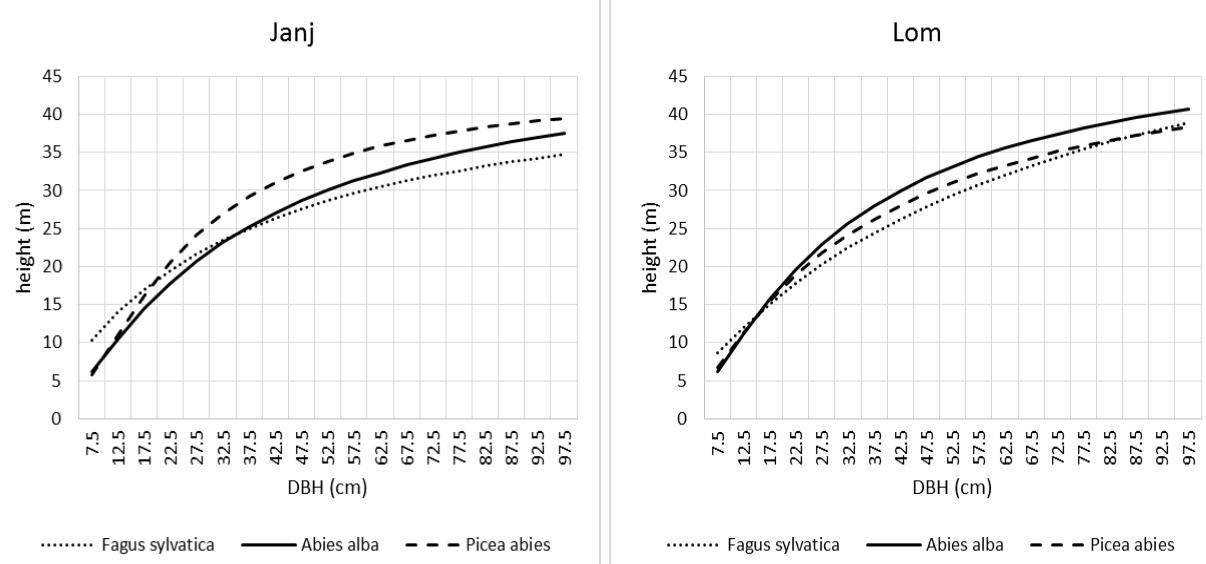

Figure 3. Height curves of fir, spruce and beech in primeval forests Janj and Lom

Both types of trees, according to the course of height curves, indicate the possibility of intensifying the height growth of thick trees of great age.

The appearance of strong height gain in thinner diameter classes and a sharp weakening in the middle ones was noted in works in primeval forests in Switzerland (Schütz, 1999). Fir trees that have not died after a long period of shading in Lom can use direct light, so smaller groups of trees that are laterally shaded by neighboring trees are excreted. That is why fir trees get an energetic increase in height and pass into the upper layer, and part of the trees remains shaded. It is a period of the intensive social ascent of trees and stratification of the stand, which is especially pronounced in Lom. Lom primeval forest is characterized by pronounced rockiness, fractures and falls of trees with a dominance of the terminal development phase (aging and decay) in contrast to Janj, where this development phase is much less represented and the stand has a larger overgrowth (Govedar, 2002). The lower heights of thinner fir trees are caused by the long stage of vegetation. Then the trees use mostly diffuse light. Later, during growth, thick fir trees in Lom reach the highest heights on average and they are larger than fir trees in Janj by about $2.3 \mathrm{~m}$, and in the thickest trees $(>\mathrm{d} 1.30=100 \mathrm{~cm})$ the differences in height are even over $4.0 \mathrm{~m}$, which reflected on the site class. For fir, these differences between Janj and Lom continuously increase with increasing diameter, while for spruce in the middle diameter classes they reach a maximum, and then decrease.

\section{Diameter increment and time of passage of fir and spruce trees}

In terms of the size of the current diameter increment, fir reacts the most concerning the stand condition and habitat conditions. The dependence of the current diameter increment on the diameter is expressed by a second-order parabola (Tab. 2) with a clearly expressed maximum function for fir and spruce trees (Fig. 4). Beech in both primeval forests has a greater increment of diameter in thinner trees (up to $32.5 \mathrm{~cm}$ ) than fir and spruce. Significant differences in 
terms of the size of the diameter increment occur with fir, which in the Lom primeval forest has a significantly higher diameter increment at the same diameters than in Janj. Large differences in diameter increment for fir are caused by differences in site classes, and for beech by a larger number of trees in the Janj primeval forest and their greater shade. The size of the current diameter increment of fir in Janj is on average $2.3 \mathrm{~mm} /$ year, and in Lom $4.5 \mathrm{~mm} /$ year. The average current diameter increment of spruce in Janj is $0.2 \mathrm{~mm}$ higher than in Lom and amounts to $2.9 \mathrm{~mm} / \mathrm{year}$. The current diameter increment of beech in Lom is significantly higher $(4.9 \mathrm{~mm} /$ year $)$ than in Janj $(2.3 \mathrm{~mm} /$ year $)$. It is characterized by a large diameter of increment in old, thick spruce trees, which is reflected in the increase in volume increment. The good physiological strength of spruce is indicated by the research results on the mountain Ljubišnja, also in beech, fir and spruce forests, where spruce can have an intensive increase in height and volume even at the age of more than 150 years (Čurović and Spalević, 2012).

Table 2. Basic statistical indicators of diameter increment dependence on diameters

\begin{tabular}{|c|c|c|c|c|c|}
\hline \multirow{2}{*}{$\begin{array}{c}\text { Primeval } \\
\text { forest }\end{array}$} & \multirow{2}{*}{ Tree species } & \multicolumn{4}{|c|}{$i d=a+a d+a d^{2}$} \\
\hline & & $\mathrm{a}$ & $\mathrm{b}$ & $\mathrm{c}$ & $\mathrm{Se}(\mathrm{m})$ \\
\hline \multirow{3}{*}{ Janj } & Abies alba & -0.371743 & 0.104912 & -0.000686 & 1.7 \\
\hline & Picea abies & -0.404252 & 0.128397 & -0.000965 & 1.6 \\
\hline & Fagus sylvatica & 1.454500 & 0.087000 & -0.001000 & 1.4 \\
\hline \multirow{3}{*}{ Lom } & Abies alba & -0.516537 & 0.142412 & -0.000778 & 2.7 \\
\hline & Picea abies & 0.726143 & 0.070432 & -0.000485 & 1.1 \\
\hline & Fagus sylvatica & 2.394100 & 0.013400 & 0.000300 & 2.3 \\
\hline
\end{tabular}

Beech in the Lom primeval forest tends to increase sharply in thickness with increasing diameter, which is caused by a significantly higher relative share of thinner than thicker trees. Fir as a highly sciophilic species (Kimmins, 1997; Stojanović and Krstić, 2008) is characterized by periods of vegetation stagnation (Pantić et al. 2011). Earlier research has indicated periods of stagnation and vegetation lasting over 200 years (Banković, 1981; Banković et al. 1994). This period can last up to 330 years in continuity, which was determined at the locality "Goč-Gvozdac" in Serbia in a mixed beech and fir forest with a stable selection structure (Pantić et al. 2015). In the period of growth stagnation, the current diameter increment was extremely low, less than $1.4 \mathrm{~mm} / \mathrm{year}$, and height increment less than $0.8 \mathrm{~m} /$ year. Oscillations during the growth of the spruce tree were determined in the research of the Lom primeval forest, where a spruce tree, $99.0 \mathrm{~cm}$ in diameter and 39.0 meters high, was analyzed (Govedar, 2005). It was found that the tree with minor oscillations had an average diameter increment in a constant and fairly uniform increase until 220 years of age, after which its values until the end of the analyzed period (420 years) remain uniform and amount to 
$0.23 \mathrm{~mm} /$ year. Based on the graphically leveled diameter increment of fir and spruce (Fig. 4) in the investigated stands, the obtained values were used to calculate the time of passage by diameters classes, by dividing the width of the diameter class $(50 \mathrm{~mm})$ by the size of the diameter increment for the thickness of the tree of a given diameter increased by $2.5 \mathrm{~cm}$.
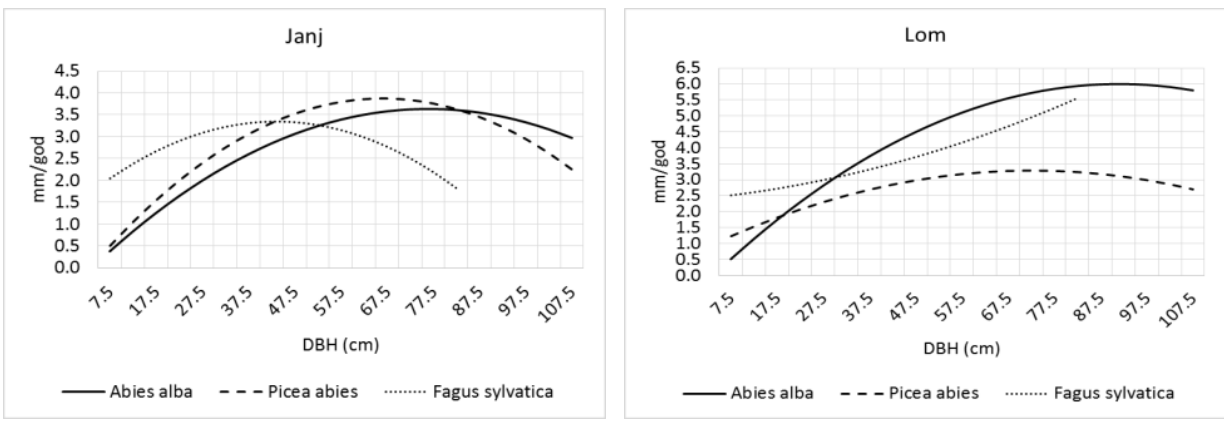

Figure 4. Dependence of diameter increment of trees on the diameter

This means that the time of passage from class $d x$ to class $d x+2.5$ is equal to the quotient between the width of the diameter class and the size of the ordinate of the increment of diameter for the abscissa $d_{x}+2.5$ read from Figure 4 . The average times of passage in the Janj primeval forest for all three tree species are longer in all, and especially in the lower diameter classes (Fig. 5). This is caused by higher overgrowth, i.e., a larger number of trees, especially fir and spruce in the Janj primeval forest. The laid course of the time lines of the passage of fir and spruce in both primeval forests at larger diameters indicates an average uniformity of growth of thick trees.

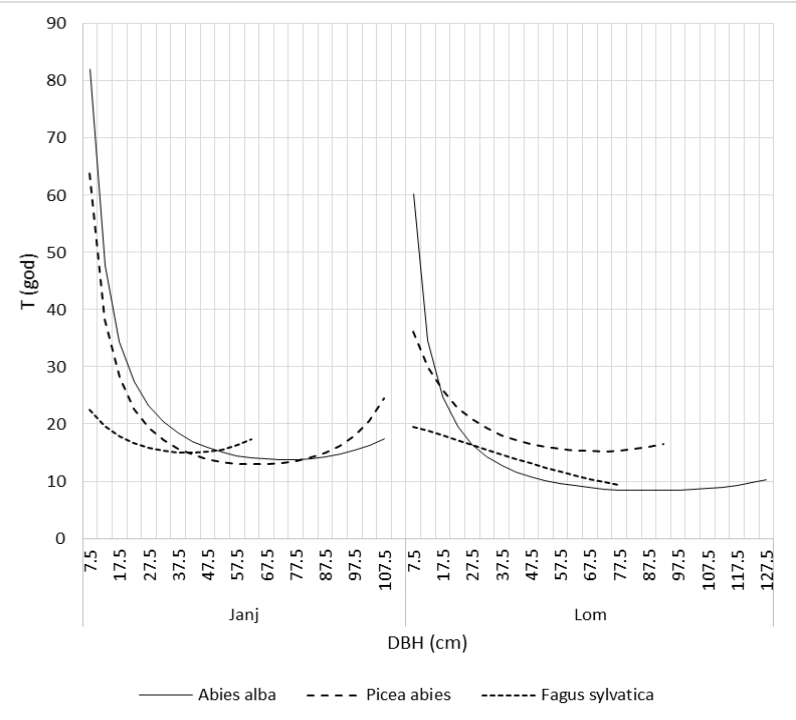

Figure 5. The average times of passage of trees 
The average time of passage of fir trees in the Janj primeval forest is the highest and for the whole stand is 45 years and the lowest for spruce in the Lom where is 22 years. Otherwise, in both stands, the time of passage of fir is about 15 years longer than in spruce trees. Beech trees in the lowest diameter classes have significantly shorter times of passage than fir and spruce. Research on Goč has indicated that beech always achieves a "currently optimal" value of the length of the time of passage earlier, i.e., in a thinner diameter class, than fir (Milin, 1961). In the case of trees thicker (over $50 \mathrm{~cm}$ ), in addition to management treatments, the influences of other environmental factors are more pronounced than in the case of thinner trees. Therefore, the times of passage of thicker trees may be a better indicator for determination of the site class, but certainly not the only one. Also, previous research on Goč in different stands of fir and beech, states that the time of passage is a parameter of low indicative ability and that as such cannot be used alone in the process of production differentiation, but in combination with several other indicators (Jović et al. 1991). Based on the time of passage of the strongest diameter classes $\left(D_{1.30}>50 \mathrm{~cm}\right)$, in commercial forests, a bound cutting cycle is determined, which is suitable for the construction of the normal condition of stands and the determination of management goals. However, the cutting cycle in the case of old-growth forests in forest reserves cannot be described as in the case of forests of economic character, but it can be a good indicator for the time dynamics of the management of diverse forests. Starting from the tax limit (DBH $=5.0 \mathrm{~cm}$ ), the relative ages of trees whose diameters are equal to the averages of the diameter classes were determined (Fig. 6).

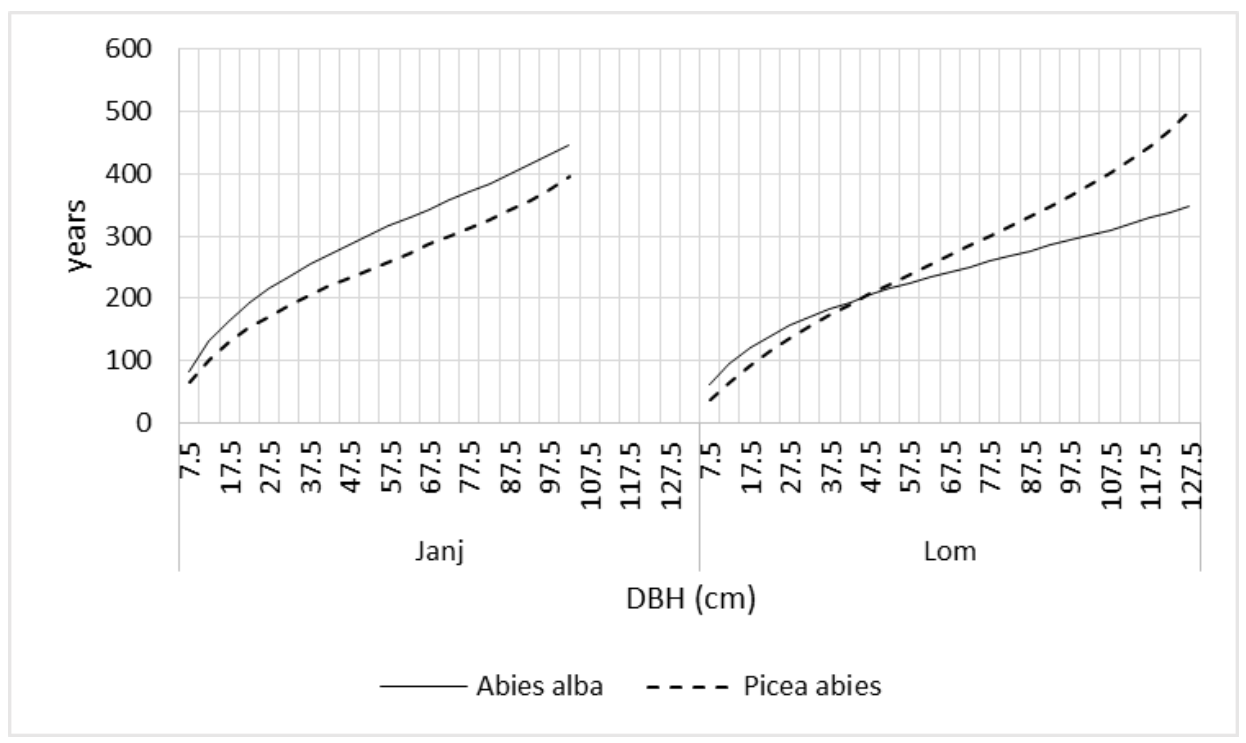

Figure 6. Relative ages of fir and spruce trees in primeval forests 
It is evident that trees with a diameter of $7.5 \mathrm{~cm}$ have a relative age equal to the time required for a tree with a thickness of $5.0 \mathrm{~cm}$ to reach a diameter of $7.5 \mathrm{~cm}$. The following values of relative ages of trees by diameter classes were calculated as cumulants "below", i.e., by successively adding appropriate times of passage to already calculated relative ages. The relative age of the strongest diameter class, under equal other conditions, can be a good indicator for assessing the internal strength of the stand as well as the strength and speed of material renewal (Miletić, 1950; Govedar et al. 2019). It is characteristic that the relative age of fir trees in Janj is higher in all diameters classes than in spruce trees. In the Lom primeval forest, the relative age of thinner fir and spruce trees is almost the same and equalizes in the middle diameters classes, after which the age of spruce trees increases sharply with increasing thickness. The fir in the Janj primeval forest is on average 85 years older than in Lom, and with the increase in diameter, it is constantly increasing. However, spruce shows the largest difference in relative age between primeval forests in thinner diameters classes and, unlike fir, the difference in age decreases with increasing diameter. Fir in primeval forests can reach an age over 500 years (Mayer, 19767; Moro, 2007).

\section{CONCLUSIONS}

The main feature of the diameter structure of trees in the studied primeval forests is the presence of ancient trees of large dimensions and very specific phenotype. The analysis of the diameter structure shows that in the lower diameter classes dominate beech with a small presence of spruce, which is caused by insufficient ingrowth. The oldest generation of trees consists mainly of highly developed and tall fir and spruce trees, and beech trees are not represented in the category of the thickest trees in stands. It has been determined that the main tree species belong mainly to the second site class. Fir in Lom reach higher heights at the same diameters, so they belong to a better quality. With thinner diameter classes, no significant difference in heights is observed.

Both types of trees, according to the course of height curves, indicate the possibility of intensifying the height growth of thick trees of great age. Thick trees, especially fir and spruce, are characterized by a uniform average increment of diameter. The average time of passage of fir trees in the Janj primeval forest is the highest and for the whole stand is 45 years, and the lowest for spruce in the Lom primeval forest where is 22 years. Otherwise, in both stands, the time of passage of fir is about 15 years longer than for spruce trees. Beech trees in the lowest diameter classes have significantly shorter times of passage than fir and spruce. The fir in the Janj primeval forest is on average 85 years older than in Lom, and with the increase of diameter, it is constantly increasing. However, spruce shows the largest difference in relative age between primeval forests in thinner diameter classes, and in contrast to fir, the difference in age decreases with increasing diameter. The average time of passage shortens with increasing diameter class, but thicker trees are not always the oldest. Since times of passage 
and relative ages are a good indicator of the internal strength of stands, they can be used to assess the degree of acceleration of production in stands.

\section{REFERENCES}

Banković, S. (1981): Effects of site and stand conditions on the development of silver fir trees in Goč and the possibilities of their harvesting under productivity differentiation of ecological units. PhD thesis, University of Belgrade, Faculty of Forestry, p 323

Banković, S., Jović, D., Medarević, M. (1994): Vegetations stadium als Merkmal in der Entwicklung der Tannenstamme in Plenterbestanden auf Goc, „Oekologie und wadbau der weisstanne“ IUFRO Symposium, pp 273-279

Barredo Cano, J.I., Brailescu, C., Teller, A., Sabatini, F.M., Mauri, A. and Janouskova, K., (2021): Mapping and assessment of primary and old-growth forests in Europe, EUR 30661 EN, Publications Office of the European Union, Luxembourg, ISBN 978-92-76-34229-8, doi:10.2760/13239

Chivulescu S, Leca S, Ciceu A, Pitar D, Apostol B (2019): Predictors of wood quality of trees in primary forests in the Southern Carpathians. Agriculture and Forestry 65 (4): 101-113

Ćirić, M., Stafanović, V., Drinić, P. (1971): Tipovi bukovih šuma i mješovitih šuma bukve, jele i smrče u Bosni i Hercegovini. Šumarski fakultet i Institut za šumarstvo u Sarajevu, Posebno izdanje, br. 8, Sarajevo

Čurović, M., Spalević, V. (2012): Development of spruce trees in mixed forests of spruce, fir and beech (Piceeto-Abieti-Fagetum) on mt. Ljubišnja. Agriculture \& Forestry, Vol 53. (07) (1-4), pp 11-18, Podgorica

Curovic, M., Stijovic, A., Spalevic, V., Dudic, B., \& Pajic, M. (2020): Structural characteristics of the mixed spruce - fir - beech forests on Mountain Bjelasica in Montenegro. Notulae Botanicae Horti Agrobotanici Cluj-Napoca, 48(3), 16991708. https://doi.org/10.15835/nbha48311992

Drinić, P. (1956): Taksacioni elementi sastojina jele, smrče i bukve prašumskog tipa u Bosni. Radovi Poljoprivredno - Šumarskog fakulteta Univerziteta u Sarajevu god. I, br. 1, str. 107-160

Drinić, P., Matić, V., Pavlić, J., Prolić, N., Stojanović, O., Vukmirović, V. (1980): Tablice taksacionih elemenata visokih i izdanačkih šuma u SR Bosni i Hercegovini. Šumarski fakultet Univerziteta u Sarajevu, Posebna izdanja br. 13, Sarajevo

Flury, Ph. (1932): Ueber Bildung von Starkeklassen bei der Forsteinrichtung. Schw.Z.f.F.w.

Fukarek, P. (1965): Prašuma Perućica nekad i danas. Posebni otisak - separatum, Narodni šumar, časopis za šumarstvo i drvnu industriju, god. XIX, sv. 1-2, Sarajevo

Govedar, Z. (2002): Elementi strukture i prirodno podmlađivanje mješovite sastojine bukve, jele i smrče u prasumi Janj. Šumarstvo, 4, 6, str. 9-24

Govedar, Z. (2005): Načini prirodnog obnavljanja mješovitih šuma jele i smrče (Abieti Piceetum illyricum) na području zapadnog dijela Republike Srpske. Doktorska disertacija, Univerzitet u Beogradu, Šumarski fakultet, str. 300 
Govedar, Z., Krstic, M., Keren, S., Babic, V., Zlokapa, B., Kanjevac, B. (2018): Actual and Balanced Stand Structure: Examples from Beech-Fir-Spruce Old-Growth Forests in the Area of the Dinarides in Bosnia and Herzegovina. Sustainability 10: $1-15$.

Govedar, Z., Krstic, M., Medarevic, M., Boncina, A., Kanjevac, B. (2019): Age and diameter growth dynamics of silver fir in the Dinaric Mountains, Bosnia and Herzegovina. Book of Abstracts, International Conference: Abies 2019 - Prospects for fir management in a changeable environment. Krakow, Poland, pp. 16.

Hufnagl, 1. (1939): Des Plenterwaldes Wirtschaftsziel, Normalbild und Einrichtung. Spr. Forstwesen, $28 \mathrm{~s}$.

Jović, D., Banković, S., Medarević, M. (1991): Proizvodne mogućnosti jele i bukve u najzastupljenijim tipovima šuma na planini Goč. Glasnik Šumarskog fakulteta, 73, Beograd

Keren, S. (2015): Complexity of stand structures in two mixed mountain old-growth forests and adjacent managed forests in Bosnia and Herzegovina. Doctoral dissertation, University of Ljubljana, Biotechnical Faculty, p 147, Ljubljana, Slovenia

Kimmins, J.P. (1997): Forest Ecology, Third Edition, University of British Columbia, New Jersey

Klepac, D. (1963): Rast i prirast šumskih vrsta drveća i sastojina; Nakladni zavod Znanje, Zagreb str. 144

Korpel, S. (1995): Die Urwalder der Westkarpaten. Gustav Fischer Verlang, Stuttgart, p 310

Mayer, H. (1977): Waldbau. Gustav Fischer Verlag, 483 p., Stuttgart-New York

Miletić, Ž. (1950): Osnovi uređivanja prebirne šume (knjiga druga). Poljoprivredno izdavačko preduzeće, Beograd

Milin, Ž. (1961): Istraživanja uticaja nadmorske visine i geološke podloge na dužinu i tok vremena prelaza jele i bukve u fakultetskoj šumi Goč - Gvozdac. Glasnik Šumarskog fakulteta, br. 25, Beograd

Moro, R. (2007): Guia de los arboles de Espana, Ediciones omega. 130-132., Barcelona

Motta R, Garbarino M, Berretti R, Bjelanovic I, Borgogno Mondino E, Čurović M, Keren S, Meloni F, Nosenzo A (2015): Structure, spatio-temporal dynamics and disturbance regime of the mixed beech - silver fir - Norway spruce old growth forest of Biogradska Gora (Montenegro). Plant Biosystems 149(6):966-975. https://doi.org/10.1080/11263504.2014.945978

Pantić, D., Banković, S., Medarević, M., Obradović, S. (2011): Some characteristics of the stagnation stage in the development of silver fi $r$ (Abies alba Mill.) trees in selection forests in Serbia. Turk J Agric For 35 (2011) 367-378

Pantić, D., Medarević, M., Dees, M., Borota, D., Tubić, B., Obradović, S., Šljukić, B., Čuković, D., Marinković, M. (2015): Analysis of the growth characteristics of a 450-year- old silver fir tree. Arch. Biol. Sci., Belgrade, 67 (1):155-160

Rozenbergar, D., Mikac, S., Anić, I., Diaci, J. (2007): Gap regeneration patterns in relationship to light heterogeneity in two old-growth beech-fir forest reserves in south-east Europe. Forestry: An international journal of forest research, 80(4) pp $431-443$

Šafar, J. (1955): Problem nadiranja i širenja bukve u arealu jele.Anali Instituta za eksperimentalno šumarstvo Jugoslavenske akademije, Vol. I, Zagreb 
Schütz, J.Ph. (1989): Der Plenterbetrieb. ETH Zurich

Stamenković, V. (1974): Prirast i proizvodnost stabala i šumskih sastojna. Izdavačko informativni centar studenata (ICS), Beograd

Stefanović, V., Beus, V., Burlica, Č., Dizdarević, H., Vukorep, I. (1983): Ekološkovegetacijska rejonizacija Bosne i Hercegovine. Šumarski fakultet u Sarajevu, Posebna izdanja, br. 17, Sarajevo

Stojanović, Lj. Krstić, M. (2008): Silviculture-Book I. University of Belgrade, Faculty of Forestry

Tregubov, V. (1941): Les forets vierges montagnardes des Alps Dinariques. Massif de Klekovatcha - Guermetch. Étude Botanique et Foresetiere. These de doctorat. Montpellier, Causse, Graille et Castelanu, p 118

Vasic, V., Pantic, D., Medarevic, M., Obradovic, S., Cukovic, D. (2018): Old-growth beech forests in Serbia. Fresenius Environmental Bulletin 27(3):1498-1507. 